\title{
Environmental impacts for polyurethane panels
}

\author{
Erika Guolo ${ }^{1,}{ }^{*}$, Francesca Cappelletti ${ }^{1}$, Piercarlo Romagnoni ${ }^{1}$, and Fabio Raggiotto ${ }^{2}$ \\ ${ }^{1}$ University IUAV of Venice, S. Croce 191, 30123 Venezia, Italy \\ ${ }^{2}$ Stiferite Spa, Viale della Navigazione interna 54/5, 35129 Padova, Italy
}

\begin{abstract}
According to the European targets for 2030, for managing a policy of improving the environmental sustainability of buildings it is essential to assess the buildings and building components impacts both in the construction and in the utilization phases. The use of building is essential on the environmental impacts (equal to about $90 \%$ ) as consequence the commitment must be aimed at reducing energy consumption and $\mathrm{CO}_{2}$ emissions of buildings during their lifetime, through correct design and proper selection of materials and technologies; above all, the use of thermal insulation materials is fundamental. A useful support tool for manufacturers and designers for the eco-design innovation of products and production processes is the LCA - Life Cycle Assessment: the assessment allows to identify and to quantify energy, consumed materials and residues released as environment impact during the processes. Comparison of the environmental impact data of the different products it is possible by adopting the EPD Environmental Product Declarations approach, which envisages, for each group of products, the elaboration of a specific technique, the PRC - Product Category Rules. In the building sector, among the thermal insulating materials currently in use, the rigid expanded polyurethane (thermoset polymeric insulation products with a substantially closed cell structure including both polymer types based on PIR and PUR), allows to obtain excellent characteristics of very low density masses, resulting in a reduction in energy consumption deriving from transport, installation and disposal or recycling at the end of life. Numerous studies on environmental impacts during the polyurethane life cycle have shown that the amount of resources consumed for the production of polyurethane foam is amortized in the use phase of buildings thanks to the energy savings determined by thermal insulation. Very important features of polyurethane is the high durability in time (higher or equal to the life of the building). This is demonstrated following some tests of physical characterization and verification of durability of rigid polyurethane insulation panels used in different types of building and construction, without maintenance: according to the determination of thermal conductivity and of the compressive strength is proven as the values are unchanged despite the years of use (over 40 years). The paper presents the LCA evaluation of a polyurethane panel; the durability of thermal properties has been verified by experimental tests.
\end{abstract}

\section{Introduction}

In order to achieve the goals set by the European Community within 2030 regarding environmental sustainability issue, three fundamental aspects must be taken into account for building sector: environmental impact, economic impact, health and comfort of the inhabitants. The latter includes many parameters such as air temperature, air humidity, air handling, lighting, noise, etc. Since about the $80 \%$ of European buildings were built before the eighties, restoration plays a key role in aiming to these goals by means of designing through a proper selection of insulating materials; in addition, using these materials leads to environmental costs reduction $[1,2,3,4]$. The choice of insulation materials must complies with the following sustainability principles [5]:

-Resources efficiency;

-Energetic efficiency;

-Pollution prevention;

-Finding local resources or materials.
Life Cycle Assessment ( $L C A$ ) is a tool which strongly supports companies to identify production and process improvement opportunities, to improve planning strategies and marketing of a product with the environmental labelling system. Sponsored by a good advertisement of sustainable construction, LCA is an evaluation method and a part of the environmental certification process of a building and it is able to quantify energy consumption, materials usage and wastes in the environment during the production process of a product [6]. Nevertheless, LCA has some limits and the most important is a lack of a standard methodology and data: many analysis are carried out only in the functional phase (a lot of data regarding the functional and disposal phase can be found in literature), but not during the life cycle [7].

To guarantee a higher eco-efficiency production, labels and product certifications (mandatory or voluntary) gained an increased interest, such as the Environmental Declaration system for products and services regard to the construction industry, "Environmental Product Declaration" (EPD): UNI EN 15804 standard - Sustainable buildings, Environmental

Corresponding author: eguolo@iuav.it 
products declaration, Develop key rules by product category - defines key rules for product categories "Product Category Rules" (IBU PCR part A: 2014-2008 V1.4, part B V06.2017); EPD and PCR define system boundaries, development of scenarios, the impacts calculation and inventory evaluation, to clearly communicate comparable, reliable and impartial information regarding environmental performances and LCA results of services and products $[8,9,10]$.

In order to evaluate the performance of insulating materials over time and over the building life-time, transmittance $(\mathrm{U})$ and/or thermal resistance $(\mathrm{R})$ figures are considered. The formula below defines the characterization modality of functional unit [6]:

$$
F U=R k \rho A
$$

Where:

$\mathrm{R}=$ thermal resistance, equal to 1 unit to be able to define the $\mathrm{FU}\left[\mathrm{m}^{2} \mathrm{~K} / \mathrm{W}\right]$

$\mathrm{k}=$ thermal conductivity $\left[\mathrm{W} \mathrm{m}^{-1} \mathrm{~K}^{-1}\right]$

$\rho=$ density $\left[\mathrm{kg} / \mathrm{m}^{3}\right]$

$\mathrm{A}=$ area, equal to 1 unit to be able to define the FU $\left[\mathrm{m}^{2}\right]$

The formula indicate the material's volume is necessary to provide a thermal resistance for all insulation durability. It is possible to use $1 \mathrm{~kg}$ of insulation as FU, indicating the quantity of material necessary for panel insulation, thermal resistance $(\mathrm{R})$, density $(\rho)$ and thermal conductivity $(k)$.

Generally, it is important to keep consideration fundamental performance of insulation, principally during life cycle and the end of life of the product [11]:

-Thermal insulation (thermal resistance and thermal conductivity);

-Mechanical characteristics (compressive strength and tensile strength) $[\mathrm{kPa}]$;

-Dimension stability [\%];

- Fire reaction [Euroclass] with system EC;

-Water absorption [\%] and water vapour diffusion resistance;

-Durability;

-Human health innocuity (environmental emission by production, transport and installation equivalent $\mathrm{CO}_{2}$, equivalent $\mathrm{SO}_{2}$, equivalent $\mathrm{PO}_{4}$ and equivalent $\mathrm{C}_{2} \mathrm{H}_{4}, \mathrm{VOC}$ );

-Acoustic performance $[\mathrm{dB}]$;

-Environmental impact (climatic changes, acidification, eutrophication, etc.);

-Cost $[€]$.

\section{The rigid expanded polyurethane}

The rigid expanded polyurethane (thermoset polymeric insulation products with a substantially closed cell structure including both polymer types based on PIR and PUR) with the same thickness compared to other insulation even of natural type, guarantees a good insulation. Moreover its lightness determines a reduction of energy consumption resulting from transport, installation and disposal or recycle to end of life; this comport a wastes reduction deriving from construction and demolition activity and is obtained and therefore a less environmental impact. Between other characteristics of material there are:

-Water absorption;

-Absence of emissions production dangerous for human and environment;

-Compressive strength;

-Reaction to fire;

-High durability (higher or equal to building life) without necessity of maintenance.

The studies of Associazione Nazionale Poliuretano Espanso (ANPE) [12] have found that the characteristics of the material over lifetime remain more or less inchanged (no physical and chemical degradation has occurred during life cycle) and the durability are equal, if not higher, to building lifetime cycle; at the end of the construction life, underlying scenarios for rigid expanded polyurethane were hypothesised:

- Reusing as insulation material in other type of construction (without metal elements);

-Energy recovery with incineration;

- Foam recovery for realization of agglomerations;

-Waste disposal.

The internal foam cannot be recovered for other agglomerates, because the gas is trapped into material until at the end of life.

Furthermore, the association and single companies of polyurethane thermal insulation have developed a numerous studies on the environmental impacts during the life cycle, highlighting as the quantity of consumed resources for the expanded polyurethane product is amortized in the use phase of building thanks to energy saving determined from thermal insulation; assuming the insulation of a pitched roof in Milan, the resources consume necessary for the production of polyurethane is amortized in the first year of using by heating plant [13].

Table 1. Milan, pitched roof with paving slab - Estimate of energy consumes and savings of the polyurethane insulation (valuation method by ENEA).

\begin{tabular}{|c|c|c|}
\hline $\begin{array}{l}\text { U existent } \\
\text { structure }\end{array}$ & $1.46 \mathrm{~W} \mathrm{~m}^{-2} \mathrm{~K}^{-1}$ & \multirow[b]{2}{*}{$\begin{array}{l}\Delta \mathrm{U}=1.18 \\
\mathrm{~W} \mathrm{~m} \mathrm{~m}^{-2} \mathrm{~K}^{-1}\end{array}$} \\
\hline $\begin{array}{l}\text { U insulation } \\
\text { structure } 80 \\
\text { mm PUR }\end{array}$ & $0.28 \mathrm{~W} \mathrm{~m}^{-2} \mathrm{~K}^{-1}$ & \\
\hline $\begin{array}{l}\text { Resources use } \\
\text { for production } \\
\text { PUR }\end{array}$ & $23,470 \mathrm{MJ}$ & \multirow{3}{*}{$\begin{array}{c}1^{\circ} \text { year }+7,169 \\
\mathrm{MJ} \mathrm{eq*}^{*} . \\
-372 \mathrm{kgCO}_{2} \\
50 \text { years } \\
+1,508,499 \mathrm{MJ} \\
\mathrm{eq}^{*} . \\
-78,441 \mathrm{kgCO}_{2}\end{array}$} \\
\hline $\begin{array}{l}\text { Energy saving } \\
\text { for year }\end{array}$ & 30,639 MJ & \\
\hline $\begin{array}{l}\text { Energy saving } \\
\text { for } 50 \text { years }\end{array}$ & $1,531,969 \mathrm{MJ}$ & \\
\hline
\end{tabular}

The recycling of thermosetting polymer, including polyurethane, is very complex because during the initial production phase there is a reticulation process which prevents the material, once formed, from being subjected to subsequent melting: a mechanical recycle takes place, in the raw material must be ground or micronized in 
particles that can be mixed with virgin material or converted into different application with respect to the starting material (floors and/or coating). The polyurethane foams can be recycled for the production of new foam, after the powder reduction of the raw material [14].

The Italian company Stiferite $\mathrm{SpA}$, is a producer of thermosetting panels in rigid expanded polyurethane with closed cells (composed of polyso - PIR foam, with higher physical and mechanical performance and reaction to fire) and was the first European company to perform the LCA evaluation with EPD certification at Swedish control entity ("The Swedish Environmental Management Council" - SEMC), starting from two products [15]: Stiferite Class S $60 \mathrm{~mm}$ and Stiferite GT $80 \mathrm{~mm}$; the evaluation of the products highlighted the limited use of resources and low environmental impact during the production process, returning the resources consumed for panel production to the environment in the form of energy saving.

All panels have different facings, designed for specific application, resulting in non-universal use. The performance are stability in time and the thermal conductivity has declared values based on the thickness: $0.025 \mathrm{~W} \mathrm{~m}^{-1} \mathrm{~K}^{-1}$ panels with thickness higher to 120 $\mathrm{mm}, 0.026 \mathrm{~W} \mathrm{~m}^{-1} \mathrm{~K}^{-1}$ panels with thickness between 120 $\mathrm{mm}$ to $80 \mathrm{~mm}, 0.027 \mathrm{~W} \mathrm{~m}^{-1} \mathrm{~K}^{-1}$ panels with thickness lower to $80 \mathrm{~mm}$.

\section{Durability measurements}

The products' durability is an essential element for estimate the performance to long term of buildings, both costs terms and both environmental impacts, it considered into the standard EN 13165:2012 Thermal insulation products for buildings - Factory made rigid polyurethane foam (PU) products - Specification.

Knowing the durability of the products is important for the insulating materials used to reduce the heat exchange between the building and the environment, playing a fundamental role in determining the costs in the operation phase of buildings (energy consumption); according to the definition of the Construction Products Regulation CPR 305/2011, durability "It is the ability of a product to maintain the required performance over time under the effect of foreseeable actions. If subjected to routine maintenance, a product must allow a duly designed work and achieved, to meet the essential requirements for an economically reasonable period. Durability depends on the intended use and maintenance conditions of a product. The durability assessment can refer to the product as a whole or to performance characteristics [...]. In both cases the basic presumption is that the performance of the product remains at an acceptable level, in relation to initial performance, throughout its useful life". With the aim of responding to this need for technical information, the Federation of European Associations for rigid expanded polyurethane (PU Europe) has entrusted FIW München with the task of evaluating the characteristics of panels installed:

-Thermal conductivity;
-Compressive strength;

-Humidity;

-Modify to dimension and product integrity.

The tests have shown the material's efficiency, which after decades of application in different construction technologies remain efficient and free of damage or defect, to respond the declaration performance [16].

Table 2. Test n.1 FIW München: polyurethane foam insulation, with coating in multilayer of aluminium on both faces, placed over the beam of pitched roof in detached house in 1982 and sample withdrawn in 2010.

\begin{tabular}{|l|c|c|}
\hline \multicolumn{1}{|c|}{ Property } & $\begin{array}{c}\text { Declared } \\
\text { values }\end{array}$ & $\begin{array}{c}\text { Values } \\
\text { measured after } \\
\text { 28 years }\end{array}$ \\
\hline Thickness & $100 \mathrm{~mm}$ & $101.08 \mathrm{~mm}$ \\
\hline $\begin{array}{l}\text { Compressive } \\
\text { strength at } 10 \%\end{array}$ & $150 \mathrm{kPa}$ & $208 \mathrm{kPa}$ \\
\hline $\begin{array}{l}\text { Thermal } \\
\text { conductivity }\end{array}$ & $0.030 \mathrm{~W} \mathrm{~m}^{-1} \mathrm{~K}^{-1}$ & $0.029 \mathrm{~W} \mathrm{~m}^{-1} \mathrm{~K}^{-1}$ \\
\hline $\begin{array}{l}\text { Thermal } \\
\text { resistance }\end{array}$ & $3.33 \mathrm{~m}^{2} \mathrm{~K} / \mathrm{W}$ & $3.49 \mathrm{~m}^{2} \mathrm{~K} / \mathrm{W}$ \\
\hline $\begin{array}{l}\Delta \% \text { thermal } \\
\text { resistance }\end{array}$ & \multicolumn{2}{|c|}{$4.55 \%$} \\
\hline
\end{tabular}

Table 3. Test n.2 FIW München: polyurethane foam insulation, placed under waterproof membrane of flat roof of the school in 1978 and sample withdrawn in 2010.

\begin{tabular}{|l|c|c|}
\hline \multicolumn{1}{|c|}{ Property } & $\begin{array}{c}\text { Declared } \\
\text { values }\end{array}$ & $\begin{array}{c}\text { Values } \\
\text { measured after } \\
\text { 33 years }\end{array}$ \\
\hline Thickness & $60 \mathrm{~mm}$ & $59,05 \mathrm{~mm}$ \\
\hline $\begin{array}{l}\text { Compressive } \\
\text { strength at } 10 \%\end{array}$ & $150 \mathrm{kPa}$ & $226 \mathrm{kPa}$ \\
\hline $\begin{array}{l}\text { Thermal } \\
\text { conductivity }\end{array}$ & $0.030 \mathrm{~W} \mathrm{~m}^{-1} \mathrm{~K}^{-1}$ & $0.027 \mathrm{~W} \mathrm{~m}^{-1} \mathrm{~K}^{-1}$ \\
\hline $\begin{array}{l}\text { Thermal } \\
\text { resistance }\end{array}$ & $2.00 \mathrm{~m}^{2} \mathrm{~K} / \mathrm{W}$ & $2.19 \mathrm{~m}^{2} \mathrm{~K} / \mathrm{W}$ \\
\hline $\begin{array}{l}\Delta \% \text { thermal } \\
\text { resistance }\end{array}$ & \multicolumn{2}{|c|}{$9.35 \%$} \\
\hline
\end{tabular}

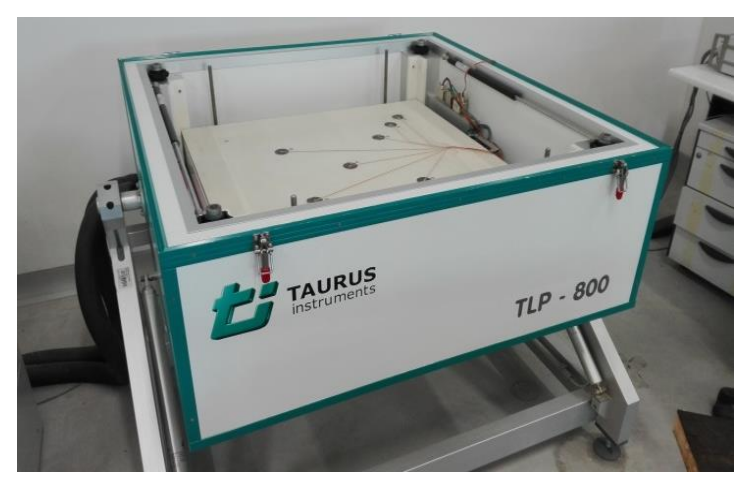

Fig. 1. Hotplate TPL 800 S, University IUAV of Venice.

Stiferite $\mathrm{SpA}$ has relied on the same durability tests of its products through a series of tests of physical characterization of polyurethane insulating panels, carried out by the University IUAV of Venice, using the 
hotplate TPL $800 \mathrm{~S}$ (double plate with guard ring, able to determine the equivalent conductivity thanks to the determination of the heat flow between the two sides of a sample of known thickness) relative to products placed in the 1982, 1988 and 1998, in various types of construction (without maintenance occurred), under restoration. It has been demonstrate how the declared values by the same company in the years of production have remained over in time, thus proving the veracity of the statements regarding the durability of the material over time (at least above 40 years).

Table 4. Test n.1 University IUAV of Venezia - Stiferite BB $40 \mathrm{~mm}$ : polyurethane foam insulation, with coating in bituminous felt paper on both faces, placed in the interspace of perimeter wall in detached house in 1982 and sample withdrawn in July 2018, following the disposal of the material in the air gap for building renovation and energy redevelopment.

\begin{tabular}{|l|c|c|}
\hline \multicolumn{1}{|c|}{ Property } & $\begin{array}{c}\text { Declared } \\
\text { values }\end{array}$ & $\begin{array}{c}\text { Values } \\
\text { measured after } \\
\text { 36 years }\end{array}$ \\
\hline Thickness & $40 \mathrm{~mm}$ & $40.83 \mathrm{~mm}$ \\
\hline $\begin{array}{l}\text { Compressive } \\
\text { strength at } 10 \%\end{array}$ & $150 \mathrm{kPa}$ & $271.15 \mathrm{kPa}$ \\
\hline $\begin{array}{l}\text { Thermal } \\
\text { conductivity }\end{array}$ & $0.028 \mathrm{~W} \mathrm{~m}^{-1} \mathrm{~K}^{-1}$ & $0.027 \mathrm{~W} \mathrm{~m}^{-1} \mathrm{~K}^{-1}$ \\
\hline $\begin{array}{l}\text { Thermal } \\
\text { resistance }\end{array}$ & $1.43 \mathrm{~m}^{2} \mathrm{~K} / \mathrm{W}$ & $1.51 \mathrm{~m}^{2} \mathrm{~K} / \mathrm{W}$ \\
\hline $\begin{array}{l}\Delta \% \text { thermal } \\
\text { resistance }\end{array}$ & \multicolumn{2}{|c|}{$5.86 \%$} \\
\hline
\end{tabular}

From these tests you notice how the life cycle of material is higher to technological plant components of buildings, estimated about 20 years in accordance to standard UNI EN 15459 [17].

Table 5. Test n.2 University IUAV of Venezia - Stiferite BB $30 \mathrm{~mm}$ : polyurethane foam insulation, with coating in bituminous felt paper on both faces, under waterproof membrane in a flat roof in a residential multi-storey building in 1998 and sample withdrawn in July 2018, following the disposal of the roofing material for the building renovation of the apartment on the top floor.

\begin{tabular}{|l|c|c|}
\hline \multicolumn{1}{|c|}{ Property } & $\begin{array}{c}\text { Declared } \\
\text { values }\end{array}$ & $\begin{array}{c}\text { Values } \\
\text { measured after } \\
\text { 20 years }\end{array}$ \\
\hline Thickness & $30 \mathrm{~mm}$ & $31.22 \mathrm{~mm}$ \\
\hline $\begin{array}{l}\text { Compressive } \\
\text { strength at } 10 \%\end{array}$ & $150 \mathrm{kPa}$ & $264.49 \mathrm{kPa}$ \\
\hline $\begin{array}{l}\text { Thermal } \\
\text { conductivity }\end{array}$ & $0.028 \mathrm{~W} \mathrm{~m}^{-1} \mathrm{~K}^{-1}$ & $0.028 \mathrm{~W} \mathrm{~m}^{-1} \mathrm{~K}^{-1}$ \\
\hline $\begin{array}{l}\text { Thermal } \\
\text { resistance }\end{array}$ & $1.07 \mathrm{~m}^{2} \mathrm{~K} / \mathrm{W}$ & $1.12 \mathrm{~m}^{2} \mathrm{~K} / \mathrm{W}$ \\
\hline $\begin{array}{l}\Delta \% \text { thermal } \\
\text { resistance }\end{array}$ & \multicolumn{2}{|c|}{$4.07 \%$} \\
\hline
\end{tabular}

Table 6. Test n.3 University IUAV of Venezia - Stiferite BB $30 \mathrm{~mm}$ : polyurethane foam insulation, with coating in bituminous felt paper on both faces, under a layer of tar aper in a pitched roof in a residential single building in 1988 and sample withdrawn in January 2019, following the disposal of the roofing material for the building renovation of a single house.

\begin{tabular}{|l|c|c|}
\hline \multicolumn{1}{|c|}{ Property } & $\begin{array}{c}\text { Declared } \\
\text { values }\end{array}$ & $\begin{array}{c}\text { Values } \\
\text { measured after } \\
\text { 31 years }\end{array}$ \\
\hline Thickness & $30 \mathrm{~mm}$ & $32.30 \mathrm{~mm}$ \\
\hline $\begin{array}{l}\text { Compressive } \\
\text { strength at } 10 \%\end{array}$ & $150 \mathrm{kPa}$ & $184.59 \mathrm{kPa}$ \\
\hline $\begin{array}{l}\text { Thermal } \\
\text { conductivity }\end{array}$ & $0.028 \mathrm{~W} \mathrm{~m}^{-1} \mathrm{~K}^{-1}$ & $0.027 \mathrm{~W} \mathrm{~m}^{-1} \mathrm{~K}^{-1}$ \\
\hline $\begin{array}{l}\text { Thermal } \\
\text { resistance }\end{array}$ & $1.07 \mathrm{~m}^{2} \mathrm{~K} / \mathrm{W}$ & $1.20 \mathrm{~m}^{2} \mathrm{~K} / \mathrm{W}$ \\
\hline $\begin{array}{l}\Delta \% \text { thermal } \\
\text { resistance }\end{array}$ & \multicolumn{2}{|c|}{$11.65 \%$} \\
\hline
\end{tabular}

\section{Methodology of application and LCA- EPD and case studies}

\subsection{Goal}

Some examples of LCA and EPD have been performed on the products of Stiferite SpA: Stiferite Class SH, Stiferite Class BH and Stiferite RP, for the year 2017. The goal is to provide verifiable information regarding the environmental aspects of the insulating product throughout life cycle, according to standard EN 15804 [9], defining the "cradle-to-gate" verification method, identifying three possible end of life scenarios: waste disposal, incinerating or recover; very often the high difficulty begins to identify the percentage and quantity of recovered and recycled material from the finished product or system.

The technical characteristics of products are determined according to standard products EN 13165 [18]. Products of rigid expanded polyurethane (PU) obtaining in factory - relatively to polyurethane products (PU) and polysocyanurate (PIR).

\subsubsection{Stiferite Class SH}

Stiferite Class $\mathrm{SH}$ is an expanded rigid polyurethane foam, covered on both sides with saturated fiber glass, with compression strength resistance of $200 \mathrm{kPa}$; the product is suggested for insulation of flat roofs under synthetic mantles in-view or weighted down and under bituminous mantles applied cold (not torched), pitched roofs, walls and floors. The standard panel format is 600 $\mathrm{mm} \times 1200 \mathrm{~mm}$, with a nominal thickness between 20 $\mathrm{mm}$ and $200 \mathrm{~mm}$. 
Table 7. Main characteristics declared relative to the product Stiferite Class SH.

\begin{tabular}{|l|c|c|}
\hline Description & Unit & Value \\
\hline $\begin{array}{l}\text { Declared thermal conductivity } \\
\text { acc. to EN } 13165\end{array}$ & $\mathrm{~W} \mathrm{~m}^{-1} \mathrm{~K}^{-1}$ & 0.028 \\
\hline $\begin{array}{l}\text { Compressive strength at } 10 \% \\
\text { of deformation acc. to EN } 826\end{array}$ & $\mathrm{kPa}$ & 200 \\
\hline $\begin{array}{l}\text { Tensile strength perpendicular } \\
\text { to the face acc. to EN 1607 }\end{array}$ & $\mathrm{kPa}$ & 40 \\
\hline $\begin{array}{l}\text { Water absorption by total } \\
\text { immersion, d<110 mm acc. to } \\
\text { EN } 12087\end{array}$ & $\%$ & 2 \\
\hline $\begin{array}{l}\text { Water absorption by total } \\
\text { immersion, d>120 mm acc. to } \\
\text { EN } 12087\end{array}$ & $\mathrm{~kg} / \mathrm{m}^{2}$ & 0.1 \\
\hline $\begin{array}{l}\text { Water absorption by partial } \\
\text { immersion acc. to EN 1609 }\end{array}$ & - & 56 \\
\hline $\begin{array}{l}\text { Water vapour diffusion } \\
\text { resistance factor acc. to EN } \\
12086\end{array}$ & Euroclass & $\mathrm{E}$ \\
\hline $\begin{array}{l}\text { Reaction to fire acc. to EN } \\
13823\end{array}$ & & 1 \\
\hline
\end{tabular}

\subsubsection{Stiferite Class $B H$}

Stiferite Class $\mathrm{BH}$ is an expanded rigid polyurethane foam, covered on the top side with bituminized glass tissue bonded to PP and on the bottom with saturated mineral glass tissue, with compression strength resistance of $200 \mathrm{kPa}$; the product is suggested for roofs under bituminous waterproofing mantles and where high resistance to a flame torch is required. The standard panel format is $600 \mathrm{~mm} \times 1200 \mathrm{~mm}$, with a nominal thickness between $30 \mathrm{~mm}$ and $200 \mathrm{~mm}$.

Table 8. Main characteristics declared relative to the product Stiferite Class BH.

\begin{tabular}{|l|c|c|}
\hline Description & Unit & Value \\
\hline $\begin{array}{l}\text { Declared thermal conductivity } \\
\text { acc. to EN 13165 }\end{array}$ & $\mathrm{W} \mathrm{m}^{-1} \mathrm{~K}^{-1}$ & 0.026 \\
\hline $\begin{array}{l}\text { Compressive strength at } 10 \% \\
\text { of deformation acc. to EN } 826\end{array}$ & $\mathrm{kPa}$ & 200 \\
\hline $\begin{array}{l}\text { Tensile strength perpendicular } \\
\text { to the face acc. to EN 1607 }\end{array}$ & $\mathrm{kPa}$ & 40 \\
\hline $\begin{array}{l}\text { Water absorption by total } \\
\text { immersion, d<110 mm acc. to } \\
\text { EN 12087 }\end{array}$ & $\%$ & 2 \\
\hline $\begin{array}{l}\text { Water absorption by total } \\
\text { immersion, d }>120 \text { mm acc. to } \\
\text { EN } 12087\end{array}$ & $\mathrm{~kg} / \mathrm{m}^{2}$ & 0.1 \\
\hline $\begin{array}{l}\text { Water absorption by partial } \\
\text { immersion acc. to EN 1609 }\end{array}$ & - & 33 \\
\hline $\begin{array}{l}\text { Water vapour diffusion } \\
\text { resistance factor acc. to EN } \\
12086\end{array}$ & Euroclass & $\mathrm{F}$ \\
\hline $\begin{array}{l}\text { Reaction to fire acc. to EN } \\
13823\end{array}$ & \\
\hline
\end{tabular}

\subsubsection{Stiferite $R P$}

Stiferite RP consist of a polyiso (PU - PIR) rigid foam panel, covered with multi-layer gas diffusion tight facers on both side and integrated vapour barrier on the hot side, bonded to a $13 \mathrm{~mm}$ plasterboard (CG); the product is suggested for insulation of internal walls and suspended metal frame ceilings. The standard panel format is $1200 \mathrm{~mm}$ x $3000 \mathrm{~mm}$, with a nominal thickness between $33 \mathrm{~mm}$ and $133 \mathrm{~mm}$. The following table shows the main characteristics declared relative to the product in question.

Table 9. Main characteristics declared relative to the product Stiferite RP.

\begin{tabular}{|l|c|c|}
\hline Description & Unit & Value \\
\hline $\begin{array}{l}\text { Declared average thermal } \\
\text { resistance acc. to EN 13950 }\end{array}$ & $\mathrm{m}^{2} \mathrm{~K} \mathrm{~W}^{-1}$ & 2.30 \\
\hline $\begin{array}{l}\text { Compressive strength at } 10 \% \\
\text { of deformation acc. to EN 826 }\end{array}$ & $\mathrm{kPa}$ & $>150$ \\
\hline $\begin{array}{l}\text { Tensile strength perpendicular } \\
\text { to the face acc. to EN 1607 }\end{array}$ & $\mathrm{kPa}$ & $>35$ \\
\hline $\begin{array}{l}\text { Water absorption by total } \\
\text { immersion acc. to EN 12087 }\end{array}$ & $\% \mathrm{~kg} / \mathrm{m}^{2}$ & $<0.1$ \\
\hline $\begin{array}{l}\text { Water absorption by partial } \\
\text { immersion acc. to EN 1609 }\end{array}$ & 164 \\
\hline $\begin{array}{l}\text { Water vapour diffusion } \\
\text { resistance factor acc. to EN } \\
12086\end{array}$ & - & $\mathrm{B} \mathrm{s} 1 \mathrm{~d} 0$ \\
\hline $\begin{array}{l}\text { Reaction to fire acc. to EN } \\
13823\end{array}$ & Euroclass \\
\hline
\end{tabular}

\subsection{Operating mode}

The functional unit, define by standard ISO 14040 Environmental management, Life Cycle Assessment, Principles and Framework [19]- allows to determine the comparability of results; in this case the functional unit declared in $1 \mathrm{~m}^{2}$.

The software utilized for life cycle modelling is $\mathrm{GaBi}$, focused on the environmental optimization of materials, energy and resources and the development of products that answer to environment requirements and norms for to improve efficiency of supplies chain [20].

The life cycle inventory allow to quantity description of all flows (material and energy) that intersect between system boundaries for creation the product. The evaluation of life cycle in exam consider the phases from supply of raw material until to disposal phase at the end of life, including the transport to building site and its installation. They are reported under the analysed phase, as listed from standard EN 15804:

A1 - extraction of raw material;

A2 - transport of raw material;

A3 - production of insulation product;

A4 - transport to building site;

A5 - installation of product;

$\mathrm{C} 2$ - transport the product at the end of life; 
$\mathrm{C} 3 / \mathrm{C} 4$ - end of life: scenarios of incineration or disposal;

$\mathrm{D}$ - recover/recycle.

In the case in question, the following system boundaries are not considered: B1 (product use), B2 (product maintenance, with transport), B3 (repair), B4 (replacement), B5 (restoration), B6 (energy use), B7 (water use), C1-C4 (deconstruction and demolition).

This choice of system boundaries depends on the facts that during the use phase of insulation material, does not require any maintenance/repair/replacement because the product is a material with high durability (as indicate in the previous paragraph) that ensure significant energy savings, in terms of consume and costs, in the building that houses it.

However, considering an average thickness of panel, at the end of life phase, a series of scenarios are evaluated with a different percentage of possible final uses, that are landfill, the incineration and recovering of material; the final results are analysed identifying the benefits deriving from the different processes.

\section{Analysis and conclusions}

The values of thermal conductivity currently measured, in some cases are even better than the values declared by the manufacturer in recent years. It is important to underline that, with the introduction of the CE labelling, the producers are required to test the materials according to harmonized standards, which provide for the declaration of a weighted thermal conductivity coefficient for a service life of 25 years referable to $90 \%$ of the production with the $90 \%$ of statistical confidence $\left(\lambda_{\mathrm{D}}\right)$, not necessarily the value that a given insulating panel can reach.

Table 10. Comparative analysis of the polyurethane panels of IUAV measures.

\begin{tabular}{|c|c|c|c|}
\hline Reference & Year & $\begin{array}{c}\text { Thermal } \\
\text { conductivity } \\
{\left[\mathrm{W} \mathbf{~ m}^{-1} \mathrm{~K}^{-1}\right]}\end{array}$ & $\begin{array}{c}\text { Thickness } \\
\text { [mm] }\end{array}$ \\
\hline \multirow{2}{*}{$\begin{array}{l}\text { University IUAV } \\
\text { of Venice (1) }\end{array}$} & 1982 & 0.028 & 40 \\
\hline & 2018 & 0.027 & 40.83 \\
\hline \multirow{2}{*}{$\begin{array}{l}\text { University IUAV } \\
\text { of Venice (2) }\end{array}$} & 1998 & 0.028 & 30 \\
\hline & 2018 & 0.028 & 31.22 \\
\hline \multirow{2}{*}{$\begin{array}{l}\text { University IUAV } \\
\text { of Venice (3) }\end{array}$} & 1988 & 0.028 & 30 \\
\hline & 2019 & 0.027 & 32.30 \\
\hline
\end{tabular}

The majority of the Italian Standards UNI previously used (UNI 9051:1987 [21], UNI 7745:1977 [22], UNI 7891:1978 [23]) instead provided for the measurement of thermal conductivity after 90 days from production, resulting in lower values being obtained.

Furthermore, since the beginning of 2004, the foaming agents directly harmful to the ozone layer (Freon 141/B) have been banned, making it mandatory the use of polyurethane foams with new eco-compatible expanding agents, decreeing however the production of new panels with lower insulating performance: this indicates that in the panels examined above, produced between the 1980s and 1990s, it is still possible to determine very low conductivity values.

The investment in the form of thermal insulation is important for the sustainability of the construction sector and as shown, this investment brings tangible economic, environmental and social benefits.

It is important to use methods of economic and environmental assessment to make the right investments in terms of construction and as analysed above, the LCA analysis is the most complete and iterative tool to achieve the objectives set by the European Community.

In the particular case reported in this paper, the LCA study is performed in compliance with standard ISO 14040 , to demonstrate the impact in the production phase of the material: after the process schematization of life process cycle, primary data are collected related to the input flow and the output flow (deriving from the site where the production process takes place), with reference to the hours [h] of production incurred during the reference period. The input refers to the raw material (of which the percentage [\%] of recycled product that composing it), to the material used for packaging of the finished product $[\mathrm{kg}$ ] (defining the quantity based on a weighted average based on the thickness in the reference year), and to the annual consumption of thermal and electric energy due to the various generation process.

The output flows are referred to waste production (description and quantity are indicated in the MUD $E D F$, Environmental Declaration Form) and in the release of atmospheric emission (VOC - Volatile Organic Compounds).

In the distribution phase, the quantity of product transported $\left[\mathrm{m}^{2}\right]$, the means of transport using (truck or ferry) and the distances travelled [ $\mathrm{km}]$ are considered, subdividing the analysis for Italian provinces, European countries and extra Europe countries.

The final objective is to structure an environmental balance with a correct allocation of data.

The collected data described, thanks to the use of software, will be transformed in analysis of environmental impacts related to the pursued functional unit. The results concerning environmental impacts and the resources used, as expected, vary according to the chosen end-of-life scenario, especially if an important percentage of material destined for disposal will be recovered (through reuse as such or chemical/mechanical recycling). From the results obtained with the GaBi software it was possible to notice how by limiting or eliminating the material disposed of in landfills or destined to the waste-to-energy process, the environmental impacts and the primary resources used in the production phase are reduced, resulting in an increase in the benefits deriving from reuse, recovery or recycling. Therefore, to increase the sustainability of the product by minimizing waste and environmental impacts and diverting the vast volumes currently destined for landfill, it is important to consider reuse as the first endof-life scenario; waste-to-energy must be taken into consideration as the last alternative of "recycling" of the material, only when the polyurethane foam has reached the end of its useful life and can no longer be used in other systems. 
The impact assessment is a quantitative and qualitative process useful for assessing the effects of the substances, which are susceptible to depletion of resources, effects on human health and environmental conservation.

The main causes of uncertainty in the assessment phase can be:

-Inaccuracy of data (measurement affects to error);

-Lack of data;

-Low representation of data (data refer to same process and not strictly related to the process considered);

-Uncertainty of the model (simplification of adopted calculate) and epistemological (acknowledge of the system);

-Variability in space and time.

All the results, data, methods, hypothesis and limitation are transparent, presented in detail and consistent with the objective of the study.

\section{References}

1. D. Anastaselos, E. Giama, A. M. Papadopolous. An assessment tool for the energy, economic and environmental evaluation of thermal insulation solutions. Energy and Buildings 41, 1165-1171 (2009).

2. L. Aditya, T.M.I. Mahlia, B. Rismanchi, H.M. Ng, M.H. Hasan, H.S.C. Metselaar, O. Muraza, H.B. Aditiya. A review on insulation materials for energy conservation in buildings. Renewable and Sustainable Energy Reviews 73, 1352-1365 (2017).

3. F.R. d'Ambrosio Alfano, F. de Leo. Materiali impermeabilizzanti e termoisolanti per l'involucro edilizio: un binomio. AiCARR Cultura e Tecnica per Energia Uomo e Ambiente, Editoriale Delfino. 2015.

4. L. Napolano, V. James. Analisi LCA comparativa di materiali isolanti tradizionali e innovativi: Il caso del progetto ELISSA. Atti del $X$ Convegno dell'Associazione Rete Italiana LCA 2016 - Life Cycle Thinking, sostenibilità ed economia circolare. Ravenna 23-24 Giugno 2016, a cura di A. Dominici Loprieno, S. Scalbi, S. Righi, 63-71 (2016).

5. F.Pacheco-Torgal, L. F. Cabeza, J. Labrincha, A. de Magalhães. Life cycle assessment (LCA) of sustainable building materials: an overview. G. K. C. Eco-efficient construction and building materials - Life cycle assessment (LCA), ecolabelling and case studies. Woodhead Publishing Series Civil and Structural Engineering 49, 38-62.

6. M. Cellura (coordinator). Life Cycle Assessment applicata all'edificio: metodologia e casi di studio sul sistema fabbricato-impianto. Editoriale Delfino. AiCARR - Cultura e Tecnica per Energia Uomo e Ambiente. 2017.

7. S. S. Shretsha, K. Biswas, A. O. Desjarlais. A protocol for lifetime energy and environmental impact assessment of building insulation materials. Environmental Impact Assessment Review 46, 25-31 (2014).

8. G.L. Baldo, M. Marino and S. Rossi. Analisi del ciclo di vita LCA. Materiali, prodotti, processi. Edizioni Ambiente Srl, 2005.

9. EN 15804:2014 Sustainability of construction works - Environmental product declarations Core rules for the product category of construction products. European Committee for Standardization.

10. M. D. Bovea, V. Ibánez-Forés, I. Augustì-Juan. Environmental Product Declaration (EPD) labelling of construction and building materials. Eco-efficient construction and building materials - Life cycle assessment (LCA), ecolabelling and case studies. F.Pacheco-Torgal, L. F. Cabeza, J. Labrincha, A. de Magalhães. Woodhead Publishing Series Civil and Structural Engineering 49, 125-150.

11. R. Dylewski, J. Adamczyk. Life cycle assessment (LCA) of building thermal insulation materials. Eco-efficient construction and building materials - Life cycle assessment (LCA), eco-labelling and case studies. F.Pacheco-Torgal, L. F. Cabeza, J. Labrincha, A. de Magalhães. Woodhead Publishing Series Civil and Structural Engineering 49, 267-286.

12. ANPE - Associazione Nazionale Poliuretano Esanso rigido. www.poliuretano.it.

13. Poliuretano \& Ambiente. Associazione Nazionale Poliuretano Esanso rigido www.poliuretano.it.

14. A. Pellizzari, E. Genovesi. Neomateriali nell'economia circolare. Edizioni Ambiente 2017.

15. Life Cycle Assessment Environmental Product Declaration. Stiferite - l'isolante termico. www.stiferite.com.

16. Durabilità dei prodotti isolanti in poliuretano. Associazione Nazionale Poliuretano Espanso rigido. Ottobre 2012.

17. UNI EN 15459-1:2018 Prestazione energetica degli edifice - Sistemi di riscaldamento e sistemi di raffrescamento idronici negli edifici Parte 1: Procedura di valutazione economica per i sistemi energetici negli edifici, Modulo M1-14. European Committee for Standardization.

18. EN 13165:2016 Thermal insulation products for buildings - Factory made rigid polyurethane foam (PU) products - Specification. European Committee for Standardization.

19. ISO 14040:2006 Environmental management Life cycle assessment - Principles and framework. European Committee for Standardization.

20. Thinkstep Gabi. www.gabi-software.com.

21. UNI 9051:1987 Materie plastiche cellulari rigide. Pannelli di poliuretano espanso rigido con parametri flessibili prodotti in continuo Tipi, requisiti e prove. 
22. UNI 7745:1977+A112:1983 Materiali isolanti. Determinazione della conduttività termica con il metodo della piastra calda con anello di guardia.

23. UNI 7891:1987+A113:1983 Materiali isolanti. Determinazione della conduttività termica con il metodo dei termoflussimetri. 